\title{
Industrial Effluent Quality of Bikaner District Rajasthan, India
}

\author{
YOGITA YADAV ${ }^{1}$, RAJENDRA SINGH ${ }^{2}$ and ADITI ${ }^{3}$ \\ ${ }^{1,3}$ Department of Chemistry, Banasthali University, Banasthali, Rajasthan, India. \\ ${ }^{2}$ Department of Chemistry, Ganpati Institute of Science Technology and Management, Jaipur, India. \\ ${ }^{*}$ Corresponding author E-mail: cynide18@ rediffmail.com \\ http://dx.doi.org/10.13005/ojc/300127
}

(Received: December 25, 2013; Accepted: February 21, 2014)

\begin{abstract}
Industrial development is an obvious process in the current world. But it is resulting in different kind of pollution to the water resources. Monitoring of industrial effluents quality and its serious analysis is very significant relative to access the human health hazards. This paper is an attempt for the same purpose. The samples were collected from main industrial areas of the Bikaner City and were analysed for the desired physiochemical parameters applying the internationally valid standard methods. Results were compared with the international standards. It was found that effluent quality is very poor leading to very dangerous health hazards as the most of the samples were not found to be fit on international and national standards. This study suggests a need to revise a more advance development and public health awareness policy as well as in depth research.
\end{abstract}

Key words: TDS, EC., chlorides, fluorides, nitrates, total hardness. BOD, TS, TSS, Physiochemical parameters, Effluent water quality.

\section{INTRODUCTION}

Development process and its regular monitoring both are the parallel issues. Bikaner district is situated at NW Rajasthan in India and there are four major heavy industrial area containing thousands of industrial unit in this developing city. Day by day these industrial units are increasing in number therefore a keen monitoring and research is required so their impact on human health and environment could be justified with the blind industrial development. Industrial waste water, effluents are the major problem for the developing industries as well as for human settlements. A serious monitoring of industrial effluent quality is very significant as this may lead to very dangerous human health and environmental hazards. However there are well defined environmental laws and guidelines provided by national agencies but it is very rare to see that these laws and regulation are being followed and these industrial units are generating the various early and delayed human health as well as environmental hazards.

\section{EXPERIMENTAL}

Four major industrial area were selected for the effluent study purpose designated as (1) 
Ranibazar, industrial area, (2) Beechwal industrial area, (3) Khara RIICO groth center, (4) Karni RIICO Industrial area. To analyse the effluent quality 12 samples from each of the above selected industrial area were collected during the time period of August 2012 to August 2013 and tested against 11 parameters in the high quality laboratory. These results were compared with the standard parameter permissible limits provided by Central pollution control board of India and further the conclusions were made. All the samples were collected and analysed using world wide acceptable methodology provided by international and national agencies like world health organization and central pollution control board of India(CPCB). All the reagents used of AR grade and the sampler as well as the glassware were used of standard quality.

\section{RESULTS AND DISCUSSION}

$\mathrm{pH}$ was found to be within the permissible limits whereas the color of effluent was observed of different kind.TSS was found highest in Khara industrial area, BOD and COD was found to be of highest value for Khara industrial Area again $(3430 \mathrm{mg} / \mathrm{l})$. Oil and grease content were found to be within the permissible limits for all areas except of karni industrial area(18.0), this high value may be attributed to the large number of wool scouring units in this industrial area. Total Chromium was found highest in Beechwal industrial area and

Table 1: Final waste water effluent outlet on land riico, rani bazar, industrial area, bikaner-2012-2013

\begin{tabular}{|c|c|c|}
\hline S.No. & Parameters & Result \\
\hline 1. & Colour vis & Dark brown \\
\hline 2. & $\mathrm{P}^{\mathrm{H}}$ & 5.950 \\
\hline 3. & Total suspended solids & 288 \\
\hline 4. & $\mathrm{COD}[\mathrm{mg} / \mathrm{l}]$ & 1723 \\
\hline 5. & $\mathrm{BOD}\left[3\right.$ days at $\left.27^{\circ} \mathrm{C}, \mathrm{mg} / \mathrm{l}\right]$ & 285 \\
\hline 6. & Oil and grease $[\mathrm{mg} / \mathrm{l}]$ & 9.0 \\
\hline 7. & Total chromium asCr mg/l & 2.317 \\
\hline 8. & Sulphides as S mg/l & 21.30 \\
\hline 9. & Chloride as $\mathrm{Cl}[\mathrm{mg} / \mathrm{l}]$ & 740 \\
\hline 10. & Sulphate as $\mathrm{So}_{4} \mathrm{mg} / \mathrm{l}$ & 765 \\
\hline 11. & $\begin{array}{l}\text { Total dissolved solids } \\
\text { [TDS]mg/l }\end{array}$ & 3520 \\
\hline
\end{tabular}

Table 2: Final waste water effluent outlet on land riico, beechwaal bazar, industrial area, bikaner-2012-13

\begin{tabular}{lll}
\hline S.No. & Parameters & Result \\
\hline 1. & Colour vis & brown \\
2. & PH & 6.71 \\
3. & Total suspended solids[mg/l] & 344 \\
4. & COD [mg/l] & 1855 \\
5. & BOD[3days at2 $\left.7^{\circ} \mathrm{C}, \mathrm{mg} / \mathrm{l}\right]$ & 313 \\
6. & Oil and grease $[\mathrm{mg} / \mathrm{l}]$ & 14.0 \\
7. & Total chromium asCr mg/l & 5.981 \\
8. & Sulphides as $\mathrm{S} \mathrm{mg/l}$ & 20.4 \\
9. & Chloride as $\mathrm{Cl}[\mathrm{mg} / \mathrm{l}]$ & 850 \\
10. & Sulphate as $\mathrm{So}_{4} \mathrm{mg} / \mathrm{l}$ & 1114 \\
11. & Total dissolved solids[TDS]mg/l & 4250 \\
\hline
\end{tabular}

Table 3: Final waste water effluent outlet on land industrial growth center khara, bikaner-2012-13

\begin{tabular}{|c|c|c|}
\hline S.No. & Parameters & Result \\
\hline \multirow[t]{2}{*}{1.} & Colour vis & Dark \\
\hline & & g ray \\
\hline 2. & $\mathrm{PH}^{\mathrm{H}}$ & 7.33 \\
\hline 3. & Total suspended solids[mg/l] & 572 \\
\hline 4. & $\mathrm{COD}[\mathrm{mg} / \mathrm{l}]$ & 3430 \\
\hline 5. & $\mathrm{BOD}\left[3\right.$ days at $\left.27^{\circ} \mathrm{C}, \mathrm{mg} / \mathrm{l}\right]$ & 488 \\
\hline 6. & Oil and grease $[\mathrm{mg} / \mathrm{l}]$ & 9.0 \\
\hline 7. & Total chromium asCr mg/l & 2.658 \\
\hline 8. & Sulphides as S mg/l & 20.9 \\
\hline 9. & Chloride as $\mathrm{Cl}[\mathrm{mg} / \mathrm{l}]$ & 320 \\
\hline 10. & Sulphate as $\mathrm{So}_{4} \mathrm{mg} / \mathrm{l}$ & 203 \\
\hline 11. & Total dissolved solids[TDS]mg/l & 2430 \\
\hline
\end{tabular}

Table 4: Final waste water effluent outlet on land karni industrial area, bikaner-2012-13

\begin{tabular}{|c|c|c|}
\hline S. No. & Parameters & Result \\
\hline 1. & Colour vis & Dark gray \\
\hline 2. & $\mathrm{P}^{\mathrm{H}}$ & 07.54 \\
\hline 3. & Total suspended solids & 280 \\
\hline 4. & $\mathrm{COD}[\mathrm{mg} / \mathrm{l}]$ & 360 \\
\hline 5. & $\mathrm{BOD}\left[3\right.$ days at $\left.27^{\circ} \mathrm{C}, \mathrm{mg} / \mathrm{l}\right]$ & 297 \\
\hline 6. & Oil and grease $[\mathrm{mg} / \mathrm{l}]$ & 18.0 \\
\hline 7. & Total chromium asCr mg/l & 2.156 \\
\hline 8. & Sulphides as S mg/l & 4.4 \\
\hline 9. & Chloride as $\mathrm{Cl}[\mathrm{mg} / \mathrm{l}]$ & 290 \\
\hline 10. & Sulphate as So $4 \mathrm{mg} / \mathrm{l}$ & 190 \\
\hline 11. & \multicolumn{2}{|c|}{ Total dissolved solids[TDS]mg// 3330} \\
\hline
\end{tabular}


can be attributed to the bulk use of dyes containing in woolen industries. TDS was found minimum for khara growth center $(2430 \mathrm{mg} / \mathrm{l})$, and maximum for Beechwal industrial area $(4250 \mathrm{mg} / \mathrm{l})$. This may be due to effluent contribution of large number of food processing unit in this area. All the parameters were found to be significant $(P=>0.5)$ for all the parameters except of oil contents and $\mathrm{pH}$.

Table 5: Refrence standard parameter for discharge of effluent on free land surface the environment (protection) rules, 1986, Govt. of india

\begin{tabular}{lll}
\hline S.No. & Parameters & Result \\
\hline 1. & Colour vis & $\begin{array}{l}\text { Colour } \\
\text { less }\end{array}$ \\
& & $5.5-9.0$ \\
2. & pH & 100 \\
3. & Total suspended solids $(\mathrm{mg} / \mathrm{l})$ & 250 \\
4. & COD $[\mathrm{mg} / \mathrm{l}]$ & 285 \\
5. & BOD[3days at $\left.27^{\circ} \mathrm{C}, \mathrm{mg} / \mathrm{l}\right]$ & 10.0 \\
6. & Oil and grease $[\mathrm{mg} / \mathrm{l}]$ & 2.0 \\
7. & Total chromium asCr $[\mathrm{mg} / \mathrm{l}]$ & 2.0 \\
8. & Sulphides as S $[\mathrm{mg} / \mathrm{l}]$ & 1.0 \\
9. & Chloride as $\mathrm{Cl}[\mathrm{mg} / \mathrm{l}]$ & 2.0 \\
10. & Sulphate as So ${ }_{4}[\mathrm{mg} / \mathrm{l}]$ & 100 \\
11. & Total dissolved solids[TDS]mg/l & \\
\hline
\end{tabular}

\section{CONCLUSION}

Results shows that the waste water effluent discharged on surface land contains high degree of pollutant load above than permissible limits .Most of the industrial units are discharging their effluents without following any standard and prescribed treatment. Study concludes that heavy pollutant load discharge on surface land leading to deterioration in soil and water resources quality as well as generation of early and delayed health hazards for sub population.

\section{Recommendations}

1. There should be a high leveled campaign with public participation to make people aware about these industrial health hazards they are getting frequently.

2. Monitoring policy must be revised and should be result oriented.

3. There should be an improved active role of public representation like NGO's and Freelance researchers for such monitoring empowered with making of penalty charges, policy and other actions.

4. A deep regular thorough high level of research promotion is required with this regard.

\section{REFERENCES}

1. State of the Environment, India, HMGN/ MOPE, 6: 15-16, 124 (2001)

2. Development Issue Vol1, Issue 2, AugustOctober 2002 p 1-4

3. Ministry of Finance (2003).

4. CBS $1998^{2}$ and * CBS 2004: Statistical Pocket books, p 187-190

5. Environmental Pollution in Nepal, A review of Studies, Kathmandu, IUCN/NPC 1991.

6. Dara, S.S., A Text Book of Environmental Chemistry and Pollution Control, p 39-42, 209-210 (2001).

7. Industrial Effluent \& their use in Agriculture along Narayani River Nawalparasi, Nepal. (Environmental \& Agriculture, at the cross road of the New millennium, 456-466 (2000).

8. Waste Water Treatment, 2nd ed. M.N. RAO, A.K. Datta, 1978, pg. 19-20)

9. Environment chemistry, $3^{\text {rd }}$ ed, 1994, A.K. De, pg., 278

10. Abbas, S.T., Salt Toleration in Pakistan Rice Varieties through Tissue Culture. Ph.D Thesis, MDS University, Ajmeer, India (1991).

11. Agarwal, S.K., Studies on the effect of the auto exhaust emission on the Mitragyna patriflora. Master Thesis, MDS University, Ajmeer, India (1999).

13. Ali, K., Javid, M.A., Javid, M., Pollution and Industrial Waste. 6th National Congress Soil Sci., Lahore, p.122-131 (1996).

13. ATSDR (Agency for Toxic Substances and Disease Registry), Toxicological Profile ofCadmium. Atlanta. US Department of Health and Human Services, Public Health Service (1993).

14. Baisberg-Påhlsson, A.M., Toxicity of heavy metals $(\mathrm{Zn}, \mathrm{Cu}, \mathrm{Cd}, \mathrm{Pb})$ to vascular plants. Water, Air Soil Pollut., 47(3-4): 287-319 
(1989). [doi:10.1007/BF00279329] Bock, R., 1979.

15. A Handbook of Decomposition Methods in Analytical Chemistry. International Texbook Company, Glasgow. Bohn, H.L., McNeal, B.L., O'Connor, G.A.K., Soil Chemistry. John Wiley and Sons, New York (1976).

16. Chaudhry, T.M., Hayes, W.J., Khan, A.G., Khoo, C.H., Phytoremediation-focusing on accumulator plants that remediate metalcontaminated soils. Australas. J. Ecotoxicol., 4: 37-51 (1998).

17. David, H.F.L., Bela, G.L., Paul, A.B., Environmental Engineers Handbook, 2nd Ed. Lewis Publishers, New York (1996).

18. Y.C. Wong, v. Maganaragi and N.A. Aliqah, Orient J. Chem., 29(4): 1421-1428 (2013).

19. Degraeve, N., Carcinogenic taratogenic and mutageniceffects of cadmium. Mutat. Res., 86: 115-135 (1981).

20. FAO, Fertilizer and Plant Nutrition Guide. Land and Water Development Division, FAO, Rome (1984).

21. Ghafoor, A., Rauf, A., Arif, M., Muzaffar, W., Chemical composition of effluents from different industries of the Faisalabad city. Pak. J. Agric. Res. Sci., 31: 367-369 (1994).

22. Groten, J.P., Vanbladeren, P., Cadmium bioavailability and health risk in food. Trends Food Sci. Technol., 5(2):50-55 (1994). [doi:10.1016/0924-2244(94)90071-X]

23. Gulfraz, M., Afzal, H., Malik, A.A., Asrar, M., Hayat, M.A., A study of water pollution caused by the effluent of various studies located in the vicinity of Sohan River. Pak. J. Sci., 49(12):13-17 (1997).

24. Gulfraz, M., Mussaddeq, Y., Khannum, R., Ahmad, T., Quality assessment of effluents from various industries in the vicinity of Rawalpindi and Islamabad. On Line J. Biol. Sci., 2(10): 697-698 (2002).

25. Hayes, A.W., Principalsand Methods in Toxicology.Raven Press, NY (1984).

26. R. Singh and Y. Yadav, Orient J. Chem., 29(4): 1661-1664 (2013).

27. Hussain, Z., Chaudhry, M.R., Zuberi, F.A., Hussain, Q., Sharif, M., Contaminants and the Soil Environment of Pakistan. In: Naidu, R., Kookana, R.S., Oliver, D.P. (1996).

28. Rogers, S., McLaughlin, M.J. (Eds.), Contaminants and the Soil Environment in the Australia-Pacific Region. Kluwer Academic Publishers, Dordrecht, the Netherlands, p.629-646.

29. Iannelli, M.A., Pietrini, F., Flore, L., Petrilli, L., Massacci, A., Antioxidant response to cadmium in Phragmites australisplants. Plant Physiol. Biochem., 40(11): 977-982 (2002). [doi: 10.1016/S0981-9428(02)01455-9]

30. Irshad, A., Ali, S., Jan, M.R., Physico-Chemical Studies of Industrial Pollutants. NSMTCC'97 on Environment Pollution. Islamabad, Pakistan. 503-514 (1997). [doi:10.1631/ jzus.2006.B0503]

31. Khan, A.G., Chaudhry, T.M., Hayes, W.J., Khoo, C.H., Hill, L., Fernandez, R., Gallardo, P., 1998. Physical, chemical and biological characteristics ofa steelworks waste site at Port Kembla, NSW, Australia. Water, Air Soil Pollut., 104(3/4): 389-402 (1997). [doi:10. 1023/A: 1004951530917]

32. Løbersli, E.M., Steinnes, E., Metal uptake in plants from a birch forest area near a copper smelter in Norway. Water, Air Soil Pollut., 37(1-2):25 (1988) .[doi:10.1007/BF00 226477]

33. Lone, M.I., Rizwan, M., Evolution of Industrial Effluents for Irrigation and Their Effect on Soil and Chemical Properties. Proc. NSMTCC 97 Environment Pollution Islamabad, Pakistan, p.269-280 (1997).

34. Schnitzer, M., Humic Substances: Chemistry and Reactions. In: Schnitzer, M., Khan, S.U. (Eds.), Soil OrganicMatter, Chapter 1. Elsevier, NY (1978).

35. Soil Fertility Survey and SoilTesting Institute, 1972. Recommendations for Irrigation Water. Directorate of Soil Fertility Survey and Soil Testing, Punjab. Totawal, K.L., Somani, L.L., Vuas, P.R., Pollution (1996).

36. US Salinity Laboratory Staff,. Diagnosis and Improvement of Saline and Alkali Soils. USDA Hand Book US Department of Agriculture, Washington DC (1954). 